\title{
Impact of abiotic factors on build-up of citrus psylla, Diaphorina citri Kuwayama population in Punjab, India
}

\author{
Hijam S. Devi ${ }^{1 *}$ and D. R. Sharma ${ }^{2}$ \\ ${ }^{1}$ Department of Entomology, Punjab Agricultural University, Ludhiana-141004, INDIA \\ ${ }^{2}$ Department of Fruit Science, Punjab Agricultural University, Ludhiana-141004, INDIA \\ *Corresponding author. E-mail: shilahijam@gmail.com
}

Received: May 13, 2014 ; Revised received: August 08, 2014 ; Accepted: September 23, 2014

\begin{abstract}
Seasonal abundance of citrus psylla (Diaphorina citri) Kuwayama was studied on Kinnow mandarin under Punjab conditions during 2012 and 2013. Population of $D$. citri was present throughout the year but only adults found surviving during December and February. There was no nymphal population when maximum temperature was $>39^{\circ} \mathrm{C}$ or $<7^{\circ} \mathrm{C}$. Two population peaks of nymphs wer e observed, first in April-May and second in AugustSeptember. Thereafter, there was abrupt decline in nymphal population during June and July during both the years when the weather conditions i.e. maximum, minimum temperature $\left({ }^{\circ} \mathrm{C}\right)$, relative humidity $(\%)$, rainfall $(\mathrm{m} \mathrm{m})$ and sunshine (hrs) ranged from 24.4-44, 22.4-31.8, 25.5-100, 0-108.0 and 0-13.5, respectively. Highest peaks of adult were found during May followed by June. With the decrease in temperature from the end of September, the population of $D$. citri started to decrease and reached its lowest during winter season. Correlation analysis for both the years indicated that maximum and minimum temperature, sunshine and rainfall were positively correlated with nymphal, adult and mixed population but the effect of rainfall on adult population was non-significant, while relative humidity was negatively correlated. The study is useful to find out the weak links of psyllid populations in relation to abiotic factors and that could be exploited to curb its infestation and disease transmission.
\end{abstract}

Keywords: Citrus psylla, Diaphorina citri, Hemiptera, Mandarin, Psyllidae, Punjab, Seasonal abundance

\section{INTRODUCTION}

Citrus is the most extensively grown fruit crop in tropical and sub-tropical regions of 114 countries with current production of 91 million tonnes in the world (Singh et al.,, 2008). Brazil ranks first in citrus production followed by USA and China. Citrus is commercially grown throughout India and occupies a place of prime importance among the major fruits of India, and ranks third after mango and banana. Its share in total fruit production in country is 12.6 per cent with an average productivity of 9.32 tonnes per ha. In Punjab (India), citrus has 48.54 thousand ha $(64.0 \%)$ with a total production and average productivity of 990.64 thousand tonnes and 20.1 tonnes/ha, respectively (Anonymous, 2013). The psyllid, Diaphorina citri Kuwayama (Hemiptera: Psyllidae) is currently one of the most important pests of world citriculture. It was discovered in 1907 in Taiwan and is today distributed across several countries of South Asia, regions of the Middle East, the Southern region of the United States, and in Central America, the Caribbean and South America (Halbert and Manjunath, 2004). This insect has become greatly important because it is the vector of the bacteria that causes huanglongbing (citrus greening), which restricts to the phloem vessels of plants
(Gravena, 2005). D. citri can be found throughout the year and it can cause damage to their host plants in various ways but the most serious damage is caused by adults through transmitting plant diseases (Yana et al., 2010). Researchers across the world are working on behaviour and ecology of $D$. citri to find out weak links in psyllid populations that could be exploited to curb its infestation and disease transmission. However, in India, information on the impact of $D$. citri is scanty since late 1960s (Sharma, 2008; 2010 and Sharma et al.,, 2011). Thus, in the context of climate change, the field study was undertaken on the population fluctuation in relation to abiotic factors on Kinnow mandarin in Punjab (India).

\section{MATERIALS AND METHODS}

The studies on the population dynamics were conducted from January to December during 2012 and 2013 in the Fruit Research Farm, Department of Fruit Science, Punjab Agricultural University, Ludhiana. The nymphal and adult populations of citrus psylla were recorded at weekly interval on Kinnow plants. The nymphal population was recorded from $10 \mathrm{~cm}$ apical portion of 5 twigs per tree while the adult population of psyllid was recorded from underside of leaf lamina from 10 older leaves/plant. Nymphal and adult counts made at 
weekly intervals were pooled month-wise and were correlated with minimum and maximum temperatures $\left({ }^{\circ} \mathrm{C}\right)$, relative humidity $(\%)$, rainfall $(\mathrm{mm})$, sunshine (hrs) and rainfall (mm) separately as well as mixed population. The daily meteorological data were obtained from the School of Climatic Change and Agricultural Meteorology, Punjab Agricultural University, Ludhiana. All the parameters were statistically analyzed following Gomez and Gomez (1984) as well as SPSS and Microsoft Excel softwares.

\section{RESULTS AND DISCUSSION}

The fluctuation of population of Diaphorina citri Kuwayama (Figs. 1-2) varied with different months of the year. Population of D. citri was present throughout the year but only adults found surviving during December and February due to extremely low temperature. During winter season when the minimum daily temperature fell below $7.4^{\circ} \mathrm{C}$, there was a decrease in adult population i.e.1.74 and 1.86 adults/10 leaves (December) and 1.28 and 1.54 adults/10 leaves (January), respectively in 2012 and 2013 with no nymphal population during this period. Low population

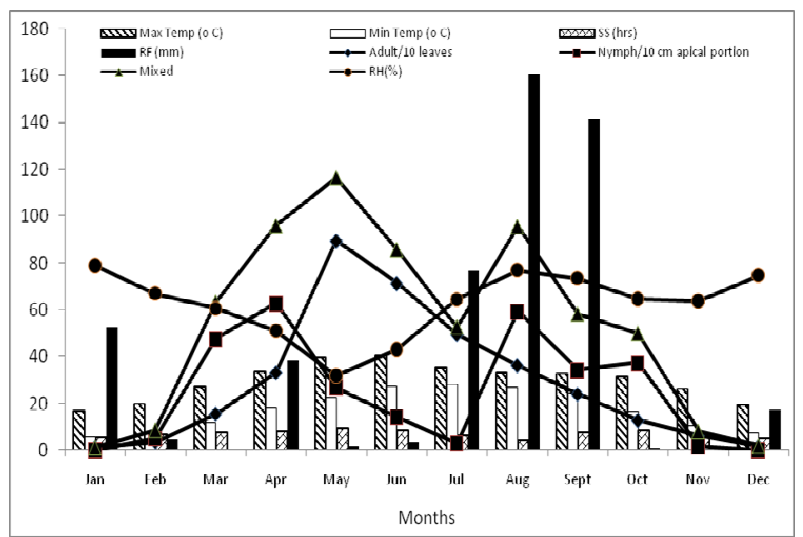

Fig. 1. Average adult and nymphal population of D. citri during different months in relation to temperature $\left({ }^{\circ} \mathrm{C}\right)$, relative humidity (\%), rainfall $(\mathrm{mm})$ and sunshine hours (hrs) during 2012.

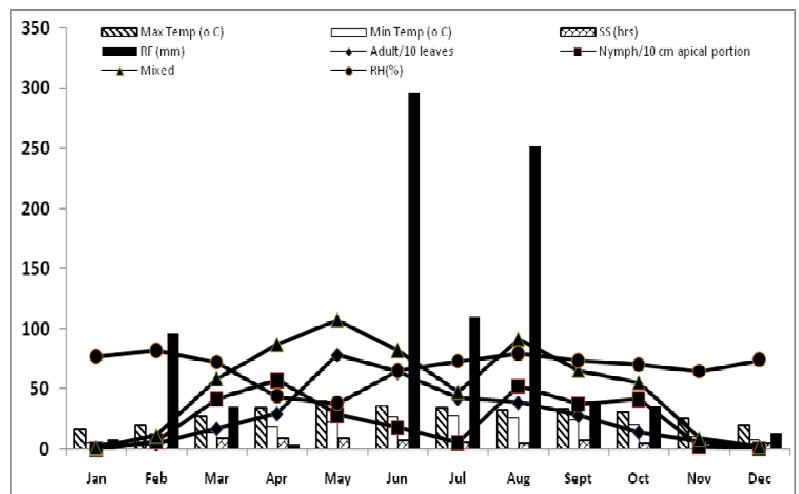

Fig. 2. Average adult and nymphal population of D. citri during different months in relation to temperature $\left({ }^{\circ} \mathrm{C}\right)$, relative humidity (\%), rainfall $(\mathrm{mm})$ and sunshine hours (hrs) during 2013.

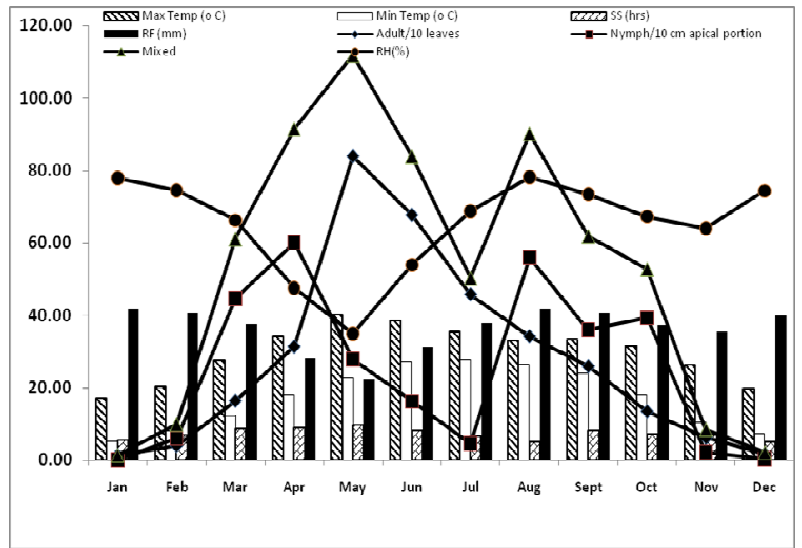

Fig. 3. Average adult and nymphal population of D. citri during different months in relation to temperature $\left({ }^{\circ} \mathrm{C}\right)$, relative humidity (\%), rainfall $(\mathrm{mm})$ and sunshine hours (hrs) over the years (2012 and 2013).

of $D$. citri observed at the beginning of both the years could be due to unfavourable weather conditions and low over-wintering adult population of the pest. This is in agreement with Lakra et al. (1983) who reported that the population of $D$. citri declined from 40 during November to 27 and 20 adults/32 leaves in December and January, respectively due to rainfall and low temperature during winter seasons. The gradual rise in daily minimum and maximum temperature from late February with decrease in relative humidity proved conducive for the build-up of the nymphal population which reached at its highest peak during April i.e. 62.7 (2012) and 57.46 (2013) and 60.08 nymphs (pooled data) $/ 10 \mathrm{~cm}$ twig. The overwintering population was also responsible for the increase in nymphal population during April. The highest mixed population of $D$. citri was found during the month of May when the maximum, minimum temperature $\left({ }^{\circ} \mathrm{C}\right)$, relative humidity $(\%)$, rainfall $(\mathrm{mm})$ and sunshine (hrs) ranged from 29.2-46.2, 17.8-31, 24-55, 0-1.6 and 0-12.6, respectively. The high population during March and April could be due to new flush as well as conducive environmental conditions as also reported from Rajasthan (Pande, 1971) and Haryana (Lakra et al., 1983). Mild winter followed by a favourable spring and pre-monsoon rains during April provides suitable conditions for a high population build-up of nymphal population. Lakra et al. (1983) observed resurgence in nymphal population from second week of April to the beginning of May and Sethi (1967) reported that population of $D$. citri reached at its maximum in March which corroborate the present findings. This is in agreement with Atwal et al. (1970) and Pande (1971). However, Sethi (1967) reported that rains received in end of March resulted in decline in nymphal population which was in variation with the present studies. The pest remained active on Citrus medica from first week of June to the end of July, second week of September to the end of December and the second week of February to the end of April, 
Table 1. Correlation and regression between adult, nymphal and mixed population of $D$. citri with different abiotic factors during 2012 and 2013.

\begin{tabular}{lcccccc}
\hline Parameters & \multicolumn{5}{c}{ Correlation during } \\
\cline { 2 - 6 } & Adult & Nymphal & Mixed & Adult & Nymphal & Mixed \\
\hline Simple correlations (r) & $0.87^{* *}$ & 0.44 & $0.87^{* *}$ & $0.89^{* *}$ & 0.56 & $0.91^{* *}$ \\
Max. Temp. $\left({ }^{\circ} \mathrm{C}\right)$ & $0.78^{* *}$ & 0.38 & $0.78^{* *}$ & $0.80^{* *}$ & 0.49 & $0.81^{* *}$ \\
Min. Temp. $\left({ }^{\circ} \mathrm{C}\right)$ & $-0.80^{* *}$ & -0.16 & $-0.66^{*}$ & $-0.59 *$ & -0.33 & $-0.58^{*}$ \\
Rel. Humidity $(\%)$ & 0.56 & 0.24 & 0.53 & 0.54 & 0.43 & $0.60 *$ \\
Sunshine (hrs) & 0.03 & 0.34 & 0.22 & 0.43 & 0.12 & 0.35 \\
Rainfall (mm) & & &
\end{tabular}

Multiple correlations ( $R$ )

\begin{tabular}{lclc}
\hline & $\mathbf{2 0 1 2}$ & $\mathbf{2 0 1 3}$ \\
\hline $\mathrm{R}_{\text {nymph }}=0.79$ & $\mathrm{R}^{2}=0.63$ & $\mathrm{R}_{\text {nymph }}=0.59$ & $\mathrm{R}^{2}=0.35$ \\
$\mathrm{R}_{\text {adult }}=0.98$ & $\mathrm{R}^{2}=0.97$ & $\mathrm{R}_{\text {adult }}=0.93$ & $\mathrm{R}^{2}=0.87$ \\
$\mathrm{R}_{\text {mixed }}=0.94$ & $\mathrm{R}^{2}=0.88$ & $\mathrm{R}_{\text {mixed }}=0.93$ & $\mathrm{R}^{2}=0.82$ \\
\hline
\end{tabular}

Multiple regression line (2012)

$\mathrm{Y}_{\text {nymph }}=-197.80+10.86 \mathrm{X}_{1}-9.13 \mathrm{X}_{2}+0.70 \mathrm{X}_{3}-1.31 \mathrm{X}_{4}+0.48 \mathrm{X}_{5}$

$\mathrm{Y}_{\text {adult }}=235.66-3.91 \mathrm{X}_{1}+4.36 \mathrm{X}_{2}-2.42 \mathrm{X}_{3}-2.19 \mathrm{X}_{4}+0.05 \mathrm{X}_{5}$

$\mathrm{Y}_{\text {mixed }}=37.86+6.95 \mathrm{X}_{1}-4.77 \mathrm{X}_{2}-1.72 \mathrm{X}_{3}-3.50 \mathrm{X}_{4}+0.54 \mathrm{X}_{5}$

Multiple regression line (2013)

$\mathrm{Y}_{\text {nymph }}=-191.74+7.20 \mathrm{X}_{1}-4.43 \mathrm{X}_{2}+1.20 \mathrm{X}_{3}-0.23 \mathrm{X}_{4}-0.05 \mathrm{X}_{5}$

$\mathrm{Y}_{\text {adult }}=156.51-3.06 \mathrm{X}_{1}+3.70 \mathrm{X}_{2}-1.78 \mathrm{X}_{3}+1.33 \mathrm{X}_{4}+0.08 \mathrm{X}_{5}$

$\mathrm{Y}_{\text {mixed }}=-35.23+4.15 \mathrm{X}_{1}-0.73 \mathrm{X}_{2}-0.58 \mathrm{X}_{3}+1.10 \mathrm{X}_{4}+0.13 \mathrm{X}_{5}$

Where, $\mathrm{X}_{1}=$ Maximum temperature $\left({ }^{\circ} \mathrm{C}\right) ; \mathrm{X}_{2}=$ Minimum temperature $\left({ }^{\circ} \mathrm{C}\right) ; \mathrm{X}_{3}=$ Relative Humidity $(\%)$; $\mathrm{X}_{4}=$ Sunshine (hrs); $\mathrm{X}_{5}=$ Rainfall $(\mathrm{mm})$

Correlation is significant at the $0.01 * *$ level and 0.05 level*

during which the nymphal population peaked three times, i.e. end of June, end of November and mid April in West Bengal (Sahu and Mandal, 1997) which are similar to the nymphal population reaching at its highest peak during April i.e. 62.7 (2012) and 57.46 (2013) and 60.08 nymphs (pooled data)/10 cm twig. However, Ahmed et al. (2004) recorded that citrus psylla population peaked in August and April but showed that environmental factors had almost no effect on the population build-up of citrus psylla which was at variation to the present studies.

Rise in maximum temperature coupled with low relative humidity during June and July and no new flush could be responsible for low nymphal population of citrus psylla (Figs. 1-3) when the maximum, minimum temperature $\left({ }^{\circ} \mathrm{C}\right)$, relative humidity $(\%)$, rainfall $(\mathrm{mm})$ and sunshine (hrs) ranged from 24.4-44, 22.4-31.8, 25.5-100, 0-108.0 and 0-13.5, respectively. Viraktamath and Bhumannavar (2002) reported that the population of $D$. citri was found usually high during March-April and July-August which was in conformity with the present studies as well as also reported by Sharma (2008).
The impact of extremes of weather parameters appeared to be more pronounced against the nymphs than the adults. A significant rise of nymphal population was observed during August (55.92 nymphs $/ 10 \mathrm{~cm}$ twig) when the daily maximum and minimum temperature $\left({ }^{\circ} \mathrm{C}\right)$, relative humidity $(\%)$, rainfall $(\mathrm{mm})$ and sunshine (hrs) ranged from 27.735.6, 23.6-29.4, 60.5-96, 0-90 and 0-11.6, respectively. The population was quite high till the end of August and thereafter psyllid population started declining may be due to non-availability of sufficient fresh growth and other environmental conditions as also reported by Mercado et al. (1991). But due to change in temperature coupled with increase of relative humidity, the nymphal population reduced from 37.2 nymphs $/ 10 \mathrm{~cm}$ twig in October to 0.2 nymphs $/ 10 \mathrm{~cm}$ twig in December (2012) and from 41.3 to 0.5 in 2013 (Figs. 1-2). Teck et al. (2011) found that D. citri population fluctuates throughout the year on Honey mandarin but nymphs were generally higher during the rainy season i.e. from October to January than during the dry season which is at variation to the present findings due to the fact that only adults could be there for whole year but nymphal 
Table 2. Correlation and regression between adult, nymphal and mixed population of $D$. citri with different abiotic factors (pooled data of 2012 and 2013).

\begin{tabular}{|c|c|c|c|}
\hline Simple correlations $(r)$ & Adult & Nymphal & Mixed \\
\hline Max. Temp. $\left({ }^{\circ} \mathrm{C}\right)$ & $0.88 * *$ & $0.50 *$ & $0.89 * *$ \\
\hline Min. Temp. $\left({ }^{\circ} \mathrm{C}\right)$ & $0.79 * *$ & $0.43 *$ & $0.79 * *$ \\
\hline Rel. Humidity (\%) & $-0.69 * *$ & -0.23 & $-0.61 * *$ \\
\hline Sunshine (hrs) & $0.54 *$ & 0.33 & $0.57 * *$ \\
\hline Rainfall (mm) & 0.23 & 0.19 & 0.28 \\
\hline \multicolumn{4}{|l|}{ Multiple correlations $(\mathbf{R})$} \\
\hline $\begin{array}{l}\mathrm{R}_{\text {nymph }}=0.59 ; \\
\mathrm{R}_{\text {adult }}=0.95 \\
\mathrm{R}_{\text {mixed }}=0.91\end{array}$ & $\begin{array}{l}\mathrm{R}^{2}=0.35 \\
\mathrm{R}^{2}=0.90 \\
\mathrm{R}^{2}=0.82\end{array}$ & & \\
\hline \multicolumn{4}{|l|}{ Multiple regression line } \\
\hline $\begin{array}{l}Y_{\text {nymph }}=-191.74+7.20 X_{1}-4.43 X_{2}+1.202 \\
Y_{\text {adult }}=156.51-3.06 X_{1}+3.70 X_{2}-1.78 X_{3} \\
Y_{\text {mixed }}=-35.23+4.15 X_{1}-0.73 X_{2}-0.58 X\end{array}$ & $\begin{array}{l}\mathrm{X}_{4}-0.05 \mathrm{X}_{5} \\
+0.08 \mathrm{X}_{5} \\
4+0.13 \mathrm{X}_{5}\end{array}$ & & \\
\hline
\end{tabular}

Where, $\mathrm{X}_{1}=$ Maximum temperature $\left({ }^{\circ} \mathrm{C}\right) ; \mathrm{X}_{2}=$ Minimum temperature $\left({ }^{\circ} \mathrm{C}\right) ; \mathrm{X}_{3}=$ Relative Humidity $(\%) ; \mathrm{X}_{4}=$ Sunshine (hrs); $\mathrm{X}_{5}=$ Rainfall $(\mathrm{mm})$; Correlation is significant at the $0.01 * *$ level and 0.05 level*

population was not found during December-January. The change in temperature coupled with increase of relative humidity reduced the nymphal population from October to December (2012), from 41.3 to 0.5 in 2013 and 39.25 to 0.34 nymphs $/ 10 \mathrm{~cm}$ twig (pooled data) (Figs. 1-3). Similar observations were also recorded by Lakra et al. (1983) who reported that the nymphal population declined to less than $1.5 / 12$ twigs during October and November and rapid fall in the population of both nymphs and adults during December when mean weekly minimum temperature fell from $24.9^{\circ} \mathrm{C}$ in September to $2.5^{\circ} \mathrm{C}$ in December. Sharma (2008) observed that adult population of of psyllid was very low during December and January but with the increase in temperature in the end of February, the activity of adults increased and there was a significant increase in nymphal population during March (41-47 nymphs/ $10 \mathrm{~cm}$ apical portion) whereas, Atwal et al. (1970) observed that at temperature of $40.0-45.0^{\circ} \mathrm{C}$ both the adults and nymphs died within few hours but was not observed in the current studies however maximum temperature $>39^{\circ} \mathrm{C}$ and $<7^{\circ} \mathrm{C}$ were found detrimental for nymphal population or females did not lay eggs.

In the present study, the maximum population of adult D. citri was observed in May during 2012 (89.53) and 2013 (78.46) and then in the month of June i.e. 71.33 (2012) and 64.22 (2013) adults/10 leaves. The higher adult population and lower nymphal population during this period demonstrated that adults were much harder to withstand the hot and dry weather than nymphs. The decrease in relative humidity or increase in temperature during April-May may have a direct impact on the emergence of adults but the subsequent increase of relative humidity and rainfall had negative influence. The results in the present studies corroborate the findings of Sharma (2008) and Gupta and Bhatia (2000) who recorded the peak populations of adults by the end of April i.e. 20.3 and 22.7/10 cm shoots. During summer season, there were noticeable differences between nymphal and adult numbers which could be due to rise in maximum temperature $\left(>39^{\circ} \mathrm{C}\right)$ and low relative humidity. The peak population of adult was found during the month of May and it remained quite high till the end of July. During this period, the maximum and minimum temperature $\left({ }^{\circ} \mathrm{C}\right)$, relative humidity $(\%)$, rainfall $(\mathrm{mm})$ and sunshine (hrs) ranged from 24.4-46.2, 17.8-31.8, 24-100, 0-108 and 0-12.6, respectively. Yamamoto et al. (2001) reported that the highest population density of $D$. citri occurred during the end of spring season and the beginning of summer season which was similar to the present findings. Thereafter, with the gradual decrease in temperature and increase in relative humidity affected the reproduction of adults and so it decreased drastically during both the years (Figs. 1-3). This was in variation as reported by McFarland and Hoy (2001) who reported an increase in $D$. citri population survival with increasing relative humidity in Florida. Tsai et al. (2002) who observed peak population of D. citri in October, November and December in 1998. In Karnataka, peak populations of psylla were recorded during January (Bhumannavar and Singh, 1985) which was in variation with the current study may be due to location factors. There was an appreciable decrease in adult population during winter (November to mid February). The population dynamics of psyllid was not significantly different during both the years.

The correlation (Tables 1-2) between nymphal, adult and mixed populations of D. citri with monthly maximum and minimum temperature $\left({ }^{\circ} \mathrm{C}\right)$, relative humidity (\%), rainfall $(\mathrm{mm})$ and sunshine (hrs) showed 
that the maximum and minimum temperature $\left({ }^{\circ} \mathrm{C}\right)$, sunshine (hrs) and rainfall (mm) were positively correlated with nymphal, adult and mixed population but the effect of rainfall on adult population was non-significant for both years. The relative humidity was negatively correlated with nymphal, adult and mixed populations of both the years (Table 1). Nehru et al. (2006) reported that there was a positive and significant correlation $(\mathrm{r}=0.876)$ between psyllid count and temperature which corroborate with the present study. Rao and Pathak (2001) also recorded maximum number of adults of $D$. citri in June in Meghalaya and found a positive correlation with minimum temperature and sunshine which was also observed in this study. Arora et al. (1997) obtained a positive correlation between temperature and psyllid population and a negative correlation with relative humidity, however, Sharma (2008) reported that minimum, maximum and mean temperatures, relative humidity and vapour pressure had a positive relation with both nymphal and adult population whereas wind velocity had very low impact on adult population. The co-efficient of determination $\left(\mathrm{R}^{2}\right)$ indicated that all abiotic factors contributed about 63.0, 97.0 and 88.0 (2012), 0.19, 76.0 and 74.0 (2013) and 0.17, 87.0 and 77.0 (overall) per cent build up of nymphs, adults and mixed population, respectively.

\section{Conclusion}

Population of $D$. citri was present throughout the year but only adults found surviving during December and February due to extremely low temperature but with the increase in temperature in the end of February, the activity of adults increased. At the same time, a low population of nymphs was also recorded and thereafter, the population of both adults and nymphs increased but significant increase in nymphal population was observed during April. A decrease in nymphal population was recorded during June-July when the adult population attained its highest peak during May. The maximum and minimum temperature $\left({ }^{\circ} \mathrm{C}\right)$, sunshine (hrs) and rainfall $(\mathrm{mm})$ were positively correlated with nymphal, adult and mixed population but the effect of rainfall on adult population was non-significant. The relative humidity was negatively correlated with |nymphal, adult and mixed populations of D. citri. The information can, therefore, be used to find out weak links in psyllid populations in relation to abiotic factors for its effective management practices.

\section{ACKNOWLEDGEMENT}

First author is thankful to the Department of Science and Technology, New Delhi to sanction INSPIRE Fellowship to conduct these studies.

\section{REFERENCES}

Ahmed, S; Nisar, A. and Khan, R.R. (2004). Studies on population dynamics and chemical control of citrus psylla, Diaphorina citri. International Journal of Agriculture and Biology, 6: 970-973.

Anonymous (2013). Fruit Area, Production and Productivity. Ministry of Agriculture, Govt. of India.

Arora, P.K; Thind, S.K; Nirmaljit, K; Grewal, I.S. and Kaur, N. (1997). Population dynamics of citrus psylla, Diaphorina citri Kuwayama on Kinnow mandarin in relation to temperature and relative humidity. Indian Journal of Ecology, 24 (2): 179-183.

Atwal, A.S; Chaudhary, J.P. and Ramzan, M.R. (1970). Studies on the development and field population of citrus psylla, Diaphoprina citri Kuwayama (Psyllidae: Homoptera). Journal of Research, 7: 333-338.

Bhumannavar, B.S. and Singh, S.P. (1985). Studies on population dynamics of citrus psylla, Diaphorina citri Kuwayama (Psyllidae: hemiptera). Entomon, 10: 63-66.

Gomez, K.A. and Gomez, A.A. (1984). Statistical Procedures for Agricultural Research. $2^{\text {nd }}$ Eds. John Wiley and sons, Inc. London, UK. 13-175 pp.

Gravena, S. (2005). Practical Handbook of Ecological Management of Citrus Pest. Gravena, Jaboticabal, SP, Brazil.

Gupta, D. and Bhatia, R. (2000). Population dynamics of the citrus psylla, Diaphorina citri Kuwayama in lower hills of Himachal Pradesh. Pest Management and Economic Zoology, 8: 41-45.

Halbert, S.E. and Manjunath, K.L. (2004). Asian citrus psyllids (Sternorryncha: Psyllidae) and greening disease of citrus: a literature review and assessment of risk in Florida. Florida Entomology, 87: 330-353.

Lakra, R.K; Singh, Z. and Kharub, W.S. (1983). Population dynamics of citrus psylla, Diaphorina citri Kuwayama in Haryana. Indian Journal of Entomology, 45: 301-10.

Mcfarland, Clint D. and Marjorie A. Hoy (2001). Survival of Diaphorina citri (Homoptera: Psyllidae), and its two parasitoids, Tamarixia radiate (Hymenoptera: Eulophidae) and Diaphorencyrtus aligarhensis (Hymenoptera: Encyrtidae), under different relative humidities and temperature regimes. Florida Entomology, 84: 227-33.

Mercado, B.G; Pableo, F; Gavarra, M.R. and Gonzales, C.I. (1991). Population studies and biological control of Diaphorina citri Kuwayama, the insect vector of citrus greening disease in the Philippines: Proceedings of $6^{\text {th }}$ International Asia Pacific Workshop on Integrated Citrus Health Management, June, 24-30. Kuala Lumpur, Malaysia, pp. 105-17.

Nehru, R.K; Bhagat, K.C. and Koul, V.K. (2006). Biology of Diaphorina citri Kuwayama on Citrus sinensis Osbeck. Environment and Ecology, 24: 443-448.

Pande, Y.D (1971). Biology of citrus psylla, Diaphorina citri Kuw. (Hemiptera: Psyllidae). Israel Journal of Entomology, 6: 307-311.

Rao, K.R. and Pathak, K.A. (2001). Field evaluation of indigenous germplasm of citrus against insect pests. Indian Journal of Hill Farming, 14: 117-119.

Sahu S.R. and Mandal, S.K. (1997). Population fluctuation of citrus psyIla, Diaphorina citri Kuwayama (Psyllidae: Hemiptera). Journal of Interacademicia, 1: 329-332.

Sethi, S.L. (1967). Insecticides for the control of citrus psylla in India. Journal of Economic Entomolgy, 60: 270-271.

Sharma, D.R. (2008). Population dynamics in relation to abiotic factors and management of citrus psylla in Punjab. Indian Journal of Horticulture, 65: 417-422.

Sharma, D.R. (2010). Current scenario of management of 
fruit pests in Punjab (Invited lecture). pp. 130-131. In: National Seminar on Recent Trends in Horticultural Crops - Issues and Strategies for Research and Development CCS. Ed: Ahlawat, V.P., Partap, P.S., Sehrawat, S.K., Rana, M.K., Dahiya, D.S., Sharma, S., Yadav, I.S., Dhankar, S.K., Rana, G.S. (eds.), Haryana Agricultural University, Hissar.

Sharma, D. R., Singh, S., Arora, P. K. and Bal, S. K. (2011). Biodiversity insect and mite pests in relation to climate change in Punjab. pp.195. Crop Improvement (Special Issue). In: International conference on Preparing Agriculture for Climate Change, held at PAU, Ludhiana, February 6-8, 2011.

Singh, S., Srivastava, A. K. and Rao, C. N. (2008). Handbook on citrus. pp. 2-3. National Research Centre for Citrus, Nagpur, Maharashtra.

Teck, S. L. C., Fatimah, A., Beattie, A., Heng, R. K. J. and King, W. S. (2011). Seasonal population dynamics of the Asian citrus psyllid, Diaphorina citri Kuwayama in Sarawak. American Journal of Agricultural and
Biological Science, 6: 527-535.

Tsai, J. H., Wang, Jin-Jun L. and Ying-Hong (2002). Seasonal abundance of the asian citrus psyllid, Diaphorina citri (Homoptera: Psyllidae) in Southern Florida. Florida Entomologist, 85: 446-451.

Viraktamath, C. A. and Bhumannavar, B. S. (2002). Biology, ecology and management of Diaphorina citri Kuwayama (Hemiptera: psyllidae). Pest Management in Horticultural Ecosysystems, 7: 1-27.

Yamamoto, P.T., Paiva, P. E. B. and Gravena, S. (2001). Population dynamics of Diaphorina citri Kuwayama (Hemiptera: psyllidae) in citrus orchards in the North of Sao Paulo State, Brazil. Neotropical Entomology, 30: $165-170$.

Yana, W., Tamesse, J. L. and Burckhardt, D. (2010). Jumping plant-lice of the family Psyllidae Latreille Hemiptera: Psylloidea) from the Center region of Cameroon: Faunistics, Phenology and host Plants. Journal of Entomology, 7: 1-18. 